\title{
Manual Vaccum Aspiration : An alterative to the standard surgical curettage, First experience in Iraq
}

\author{
Dr. Azhar A. AL-Adhub \\ F.I.C.O.G. , D.O.G. , Member of British Fertility Society and ESHRE
}

\begin{abstract}
Manual vacuum aspiration ( MVA ) or Karmah Cannula is a soft flexible Cannula invented by Harvey Karman in early 1970s . This can be performed under local anesthesia in the setting of a treatment room and office .

The aim of this study: To assess the efficacy of MVA in the management of first trimester early fetal demise, missed abortion up to 13 weeks and incomplete miscarriage, and it if can be used as successful alternative to traditional method of sharp surgical curettage
\end{abstract}

Material and method: This was an interventional prospective study including 200 patients who were scheduled to undergo MVA for $1^{\text {st }}$ trimester early fetal demise and incomplete miscarriage. The study population consist of 200 patients who were diagnosed as having missed abortion by ultrasound abdominal and Trans-vaginal ultrasound. The study conducted between January 2014 - until January 2016 . The efficacy assessed by completion of evacuation evaluated immediately by ultrasound conducted in the same clinic and second look ultrasound after one week of the procedure .

Result: Efficacy of the procedure was $99 \%$ and incomplete uterine evacuation was seen in $1 \%$ of patients . No significant rate of complication like uterine perforation, infection, or excessive vaginal bleeding .

More than $99 \%$ of cases has a successful procedure and did not required any further surgical or medical treatment $98 \%$ of women were satisfied with the procedure and they will recommend it to others .

This study proved that MVA is super to the traditional use of D \& C with metallic tools by avoidance of hospital stay and general anesthesia and will decrease the daily work load for medical staff.

\section{Conclusion :}

Manual vacuum Aspirator ( MVA ) is safe, effective and minimally invasive procedure with low rate of complication .

Moreover, it can be carried our safely and effectively in office or medical clinic and no need for hospital admission, occupying the operating theatre and medical staff 
involvement. It even cost effective in comparism with surgical dilatation and curettage which is held under general anesthesia in operating theatre of Hospitals .

Recommendation: This study may change the traditional use of dilatation and curettage with metallic tools and replaced by MVA with avoiding of general anesthesia and the need for access to the theater

\section{Introduction}

Miscarriage rate in Iraq mean values of spontaneous and missed abortion per 1000 pregnancies has increased by two fold from first survey interval of 1988 1992 to last interval $2008-2012$. $^{(1)}$

The abortion / miscarriage rate ( 2006 / 2007 ) survey conducted by Iraqi $\mathrm{MOH}$ and WHO/Iraq showed this rate as $78 / 1000$ pregnancy in south and center regions of Iraq and $99 / 1000$ in Kurdistan Iraq abortion / miscarriages in Iraq are higher than neighboring countries . ${ }^{(1)}$

Miscarriage occur in $10-20$ of clinically recognized pregnancies and account for 50.00 in patient admissions in the UK annually . (2)

The world health organization estimates that 46 million pregnancies end in abortion each years and nearly 20 million of these are through to be unsafe

WHO 2003 ). (3)

In fact unsafe abortion is one of the leading causes of maternal mortality in India , the number of abortions is steadily rising each year the number of death due to unsafe abortion has also been steadily increase . ${ }^{(4)}$

The available treatment options for first and early $2^{\text {nd }}$ trimester miscarriage includes surgical, medical and expectant management . ${ }^{(2,5)}$

Up to $88 \%$ of women with miscarriage undergo surgical evacuation under GA. ${ }^{(2)}$ MVA can be performed under local anesthetics and may has advantage both for the patient and health care system . ${ }^{(2)}$ MVA has been widely used in the USA and many African, Asian and European countries, as a successful alternative to D \& $\mathrm{C}$ and was first described in the 1970s initially for the management of incomplete miscarriage, but it's use has been extended for the management of missed miscarriage and termination of pregnancy . ${ }^{(1,3)}$

During MVA, a $60 \mathrm{ml}$ hand held ' syringee with a self locking plunger is used to produce the vacuum needed for the aspiration of products of conception it is, performed under local anesthesia in the office, it's an out patient procedure, thus avoiding the need for the use of on 
operating theater and the risk of GA and can be used as disposable tool with different catheter sizes that avoid the need for dilatation of cervix . (6-8)

Complication of MVA are similar to electrical suction curettage and include fail or to completely evacuate the uterus , infection, bleeding and in un experienced hands uterine perforation and cervical laceration can be occurred.

The aim of our study was to assess the effectiveness of MVA following the diagnosis of first trimester early fetal demise and first and mid trimester incomplete miscarriage ${ }^{(1,9,10)}$

\section{Material and Methods}

Study type: This study is a interventional prospective study, where all women who underwent MVA was in first the trimester.

The study was conducted between January 2014 until February 2016 .

Place: Data collected in Al-Habboby Teaching hospital obstetric department in prospective manner.

Outcome and study componant: A primary measure was to assess the efficacy of the procedure defined as complete uterine evacuation without the need for further treatment medical or surgical re curettage.
Secondary out come measure including safety of the procedure and rate of complications and the patient compliance to procedure .

MVA was offered as a treatment option to women who had been diagnosed with early fetal demise or required an evacuation following failed medical treatment of miscarriage at gestational age less than 14 weeks .

Gestational age was calculated by LMP and ultra-sound .

A part from MVA all women were offered the choice of medical, surgical and expectant management, women were offered option of MVA after full counseling on what to expect during the procedure .

As per protocol all women were administered 800 microgram of sublingual Misoprostol for ripening of the cervix $3-4$ hours before the procedure, unless the procedure was planed following failed medical treatment or the cervix ripening was enough. A total number of 200 patient were studied randomly .

\section{Exclusion criteria include :}

1. Gestational age more than 13 weeks .

2. Uterine fibroids .

3. Suspected ectopic pregnancy . 
4. Bleeding disorders .

\section{Preliminary investigation includes}

1) $\mathrm{Hb}, \mathrm{PCV}, \mathrm{Blood}$ group and $\mathrm{Rh}$.

2) RBS

3) Coagulation profile.

\section{Procedure started with :}

1. Patient counseling

2. ultrasound examination which is done two times $1^{\text {st }}$ time before the procedure and $2^{\text {nd }} U / S$ after finish the procedure to be sure that the uterus was completely evacuated .

3. give Diazepam injection $10 \mathrm{mg}$ intramuscularly at the beginning .

4.the uterus was evaluated by bimanual exam then the size of uterine catheter selected accordingly ( each disposable MVA system contain 3 different sizes of uterine catheter $4 \mathrm{~mm} 8 \mathrm{~mm} 12 \mathrm{~mm}$ to sungly fit in the cervical canal ).

5. bilateral cervical nerve block done by lignocain $2 \%$ to reduce the pain of the procedure, vacuum was created in $60 \mathrm{ml}$ single valve MVA syringe (i.e. ) the syringe was charged .

6.The cannula was inserted through the cervix to words the fundus. The charged syringe was attached to the cannula .

7.The charged syringe value released allowing the vacuum to get transferred to the uterine carity. The system was started and in few minutes the products of conception was aspirated into the operation syringe .

8.The cannula was turned around 180 degree on it's longitudinal axis and to and fro movements its was taken out once or twice, signs of completion same as dilatation and curettage Appearance of red - pink foam or bubbles, absence of more products getting aspirated, a gritting sensation as the cannula passes over the uterine wall and a feel of the uterus contracted around the cannula was considered as signs of completeness of procedure .

9-Usually the procedure done with intravenous fluid loaded with oxytoxin 10 IU controlled drip to avoid any excessive bleeding .

All women in this study were in the first trimester rang from $8-12$ weeks median gestational age being 10 weeks and most of patient was mulitipara . If after administration of misoprostol, women experience heavy vaginal bleeding or passed products of conception, a pelvic examination and or ultrasound exam was performed to ensure that the MVA was still indicated .

10-Prophylactic antibiotics were not routinely administered all women were 
screened for Genital tract infection and treated accordingly .

The procedures was performed by a team( obstetrician doctor and assistances) 11-During the MVA anesthetic gel lidocaine was applied to the cervix and subsequently local anesthesia was administered in Para cervical area at 2, 4 , 8 and 10 o'clock informal injectable lignocain $2 \%$ injection .

12-Products and congtion where send for histopathogical evaluation .

13-Anti D prophylaxis was administered to all $\mathrm{Rh}-\mathrm{ve}$ women .

Patient could be discharge $2 \mathrm{hr}$. post MVA if they were clinically well haemodynamically stable, with minimal bleeding and pain .

Advising her with oral antibiotics and analgesics . all patient give an appointment to come for follow up after one week and again after 6 weeks (as by then she is expected to have resume her ministration and that time give her plane for family planning .

Feasibility assessed through successful completion of the procedure without the need for GA or conversion to mechanical $\mathrm{D} \& \mathrm{C}$.

And efficacy assessed through completion of uterine evacuation without the need for further medical or surgical intervention .

Follow up: patient usually advised to contact us on $24 \mathrm{hr}$. basis if any concern or problem a rise following MVA, usually we give the patient The clinic contact number and patient given an appointment after one week to reevaluate her condition and record any complication that could be happened .

\section{Ethical Consideration:}

A written consent had been taken from the hospital administration, and all patients in this study gives the verbal consent for doing the procedure After counseling, even though MVA is a simple procedure.

\section{Statistical analysis}

Data would be analyzed using Statistical Package for Social Sciences (SPSS) version 24. For categorical variables, frequencies and percentages would be reported. Differences between groups would be analyzed using chisquare test. For continuous variables, means and standard deviations would be used to present the central location and their dispersion .A P-value $<0.05$ would be considered statistically significant. 


\section{Results:}

\section{1-Patient Characters:}

Table ( 1 ). Distribution study subjects according to age and parity

\begin{tabular}{|c|c|}
\hline Age ( years ) & Number of patients \% \\
\hline$<20$ & $26(13 \%)$ \\
\hline $20-30$ & $50(25 \%)$ \\
\hline $30-40$ & $120(60 \%)$ \\
\hline 40 & $4(2 \%)$ \\
\hline Total & 200 \\
\hline
\end{tabular}

\begin{tabular}{|c|c|}
\hline Parity & No. $\%$ \\
\hline Nulliparous & $\mathbf{8 0}(\mathbf{4 0 \%})$ \\
\hline Multiparous & $\mathbf{1 2 0}(\mathbf{6 \%})$ \\
\hline Total & $\mathbf{2 0 0}$ \\
\hline
\end{tabular}

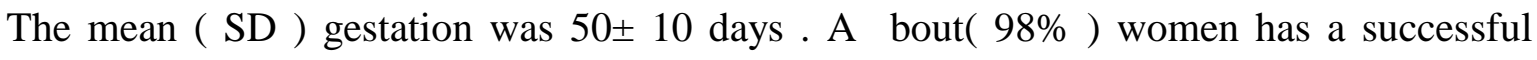
procedure and did not required any further surgical or medical treatment .

2-Complications: In this study samples did not have any major complication, No one need hospital admission because no excessive bleeding, uterine perforation or heavy vaginal bleeding or serious complication that need staying in hospital .

3-Patient satisfaction: The forma of the satisfaction had been filled for only 60 patients, where,

Fifty-five ( $98 \%$ ) women were satisfied with the procedure $48(86 \%)$ said they would recommend it to a friend \& 45 ( $80 \%$ ) said they would have the same method again in the future if they experience a miscarry again .

4-Anxiety levels: It had been assessed also as reflected by the visual analogue scales , showed a significant fall in anxiety scores following the procedure $(\mathrm{P}<0.01)$. 


\section{Discussion}

The aim of our study is to assess the efficacy and safety of MVA in the management of early pregnancy loss .

It has been shown that MVA is a safe and effective method of uterine evacuation and has been successfully used for the management of missed abortion of first trimester,

No one need hospital admission because no excessive bleeding or serious complication that need admission .

The risk of any complication with MVA is relatively small .

In this study samples did not have any major complication such as uterine perforation or heavy vaginal bleeding .

The rate of incomplete evacuation after dilatation and curettage ( D \& C ) is reported approximately $2-3 \%$ and this is approximately the same for MVA our result showed a lower rate of incomplete evacuation $0.5 \%$ however this one patient not required reevacuation by surgical D \& C and management conservatively by given 4 tablets 800 microgram of misiprostol sublingually and repeat ultrasound scan after one week which show empty cavity with out any retained products and conception .
This lower rate of retained products may be attributed to ultrasound monitoring after each single procedure immediately after MVA procedure in addition all procedures done by a single senior specialist doctor in obstetric and gynecology. The procedure in general was very well tolerated may be because selected sample population was fully counseled about what to expect the local anesthesia, in addition to uses of different sizes of uterine catheters that fit the size and cervix .

In this study researcher did not assess separately women's perceptions and expectations before and after the procedure and this is something that should be evaluated in the future studies, however in our study surgical evacuation by MVA, a high acceptability of procedure was reported and $99 \%$ of women were satisfied with the procedure.

This proved that MVA has advantage over standard surgical curettage for both the patient and the health care providers in reducing hospital cost waiting time and hospital stay .

So avoid GA with all it's associated risks and cost and hospital stay .

This is beneficial for our practice in Iraq since our operating theater is used for obstetric emergencies specially with increasing population size in Thi-Qar ( 
more than 2 million ) and only two hospitals in the centre of Nassiryah so with the use of MVA in office, medical clinics it reduces the load to resident doctors, house officer registrar and senior on call and sub staff .

MVA as an alternative surgical option for he management of early pregnancy loss is thus well tolerated and may have potential economic benefits .

This should ideally be corroborated in the context randomized controlled studies comparing MVA and Standard Mechanical curettage .

All patients in this study gives the verbal consent for doing the procedure After counseling, even though MVA is a simple procedure, which doesn't require sophisticated equipment it is infrequently used in Iraq or never used before because the doctors and health care providers not familial with it and not have enough experience to doing this procedure that's why we do this study in order to show the benefits of MVA to patient and health care system in Iraq .

Furthermore, unfamiliarity of clinicians with this technique and lack of confidence among midwifery staff in counseling women could be contributing factor. In addition, staff training and junior doctor training should be an issue due to the high anxiety in this cohort of women and the fact that the procedure is being under taken under local anesthetic. The researcher believed that this study may help to raise awareness and interest in this method and increase it's acceptance in Thi-Qar and all over the Iraq government for management of first trimester miscarriage .

\section{Key message points}

- Surgical abortion using manual vacuum aspiration under local anesthesia appears to be feasible acceptable to women .

- $\quad$ The procedure can be performed on an outpatient basis thus reducing the cost and burden on day surgery lists . This may have implications for health service provision .

- These findings, as well as the cost implications of this approach, now need to be assessed in the context of a randomized trial .

\section{Conclusion}

The MVA is a safe easily performed and possibly cost effective procedure with advantages for the patient and health care system . 
It could be considered routinely as an alternative option for the management of early fetal demise MVA is an effective alternative to traditional mechanical curettage thus avoiding GA and the need or access to the theatre .

\section{References}

1- $\quad$ DS Millingos, M Mathur, NC Smith , PWA shock, Manual Vacuum Aspiration : a safe alternative for the surgical management of early pregnancy loss . BMJO August 2009 . $116,1268-1271$.

2- Bradley E, Hamilton Fairely D. Managing miscarriage in early pregnancy assessment units . Hosp Med 1998 ; 59 ; 451 - 6 .

3- Hemminki E, Treatment of miscarriage : current practice and rationale . Obstet Gynecol 1998 ; 91 : $247-53$.

4- World Health Organization . Safe motherhood : care of mother and baby at the health care center. A practical Guide. Maternal Health and safe motherhood Programme. Geneva : WHO Division of family Health ; 1994

5- Creinin MD, Schwartz JL , Guide RS , Pymar HC . Early pregnancy failure $\quad-\quad$ current management concepts . Obstetric \& Gynecological sur $2001 ; 2: 103-13$.

6- $\quad$ EK wempu CC 1990. Uterine aspiration using the Karmar cannula and syringee . Tropical Journal of obstetric and Gynecology . 8(2). 37-8 .

7- Adinma , JI ; Adinma , E. Jarman's Cannula and Vacuum aspiration in Gynecological practice. Journal of the National Medical Association 88(1): 22 - 4 8 Hamoda H. Flett GMM , Ashok PW , Templeton A. Surgical abortion using manual Vacuum aspiration under local anesthetic : a pilot study of feasibility . J fam plan Reprod Health care 2005 ; 31 : $185-8$.

9- $\quad$ Mohamed Bedewi .Manual vacuum aspiration: a safe and cost-effective substitute for dilatation and curettage on the surgical management of First-Trimester Abortion, Journal of American Science 2013;9(6)

10- Vacuum Aspiration : A summary of Clinical and Programmatic Experience worldwide . Carrboro, NC : IPAS ; 1993 .

11- Ministry of Health and WHO , Iraq family Health survey 2006 / 2007 


\section{استخدام الثفط الهوائي اليدوي بديلا لعملية الكحت الحاد او الكحت والتوسعة

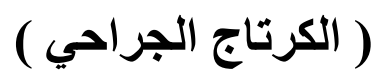 \\ د. أزهار عبد الكاظم عبد الرزاق العضب

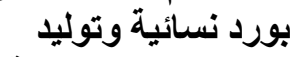 \\ مستثفى الحبوبي / دائرة صحة ذبوني ذبار}

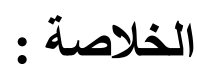

استعمال الشفط الهو ائي هي طريقة آمنه وبدون ألم تستعمل بديلا للكحت و التوسعة وتتم عن

طريق الشفط الهوائي بكانيو لا اسمها ( كارمان كانيو لا ) و هي جهاز بلاستيكي و غير مؤذي للرحم . يتم تحضير عنق الرحم عن طريق PG بروسـتاغلاندين قبـل اجر اء العمليـة مـع استعمال مسكنات بسيطة ، تقيم الكفاءة باجر اء سونار مباثرةً بعد العملية للتأكد من ان كل محتويـات الرحم قد افرغت بالكامل ، تصل كفاءتها الى 99\% وتستخدم لافر اغ الرحم من الاسقاط المنسي وبقايـا الاسقاط الناقص للتثلاث الأشهر الاولى من الحمل حتى با اسبوع من الحمل . جهاز الثفط هو يدوي ومناسب ويلبي رغبة السيدات وهنالك توصية عامة من منظمـة الصحة العالميـة باستعمال الشفط بدلا من الكورتاج وذللك لأنه أقل كلفة ويقلل الزخم على المستشفيات و على صالات العمليات ولا يحتاج تخدير عـام ، ولا نوجد بـه مضـاعفات مثل النزف ، الألم ، ثقب الرحم ،

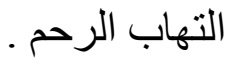

وبذللك نكون قد وفرناوقت وجهد وتكلفة على المستشفيات والاطباء و الممرضين ـ وتعتبر هذه الدر اسة أول تجربة في العراق ، ونوصي بشدة باتباعها في كل محافظات العراق . 
Thi-Qar Medical Journal (TQMJ): Vol.(14), No.(2), 2017 Email:utjmed@utq.edu.iq

Web Site: https://jmed.utq.edu.iq 